\title{
Occurrence and origin of submarine plunge pools at the base of the US continental slope
}

\author{
Simon E. Lee ${ }^{\mathrm{a}, *}$, Peter J. Talling ${ }^{\mathrm{a}}$, Gerald G.J. Ernst ${ }^{\mathrm{a}}$, Andrew J. Hogg ${ }^{\mathrm{b}}$ \\ a Department of Earth Sciences, Centre for Environmental and Geophysical Flows, University of Bristol, Wills Memorial Building, \\ Queens Road, Bristol BS8 1RJ, UK \\ b School of Mathematics, Centre for Environmental and Geophysical Flows, University of Bristol, Bristol BS8 1RJ, UK
}

Received 7 July 2000; accepted 12 November 2001

\begin{abstract}
High-resolution bathymetric data from the New Jersey and Californian continental margins show a marked depression running along parts of the base of the continental slope. Detailed analysis reveals that the depressions are a series of discrete 'plunge pools' with associated downslope topographic ramparts. We have used new bathymetric data to create our own data base (of over 150 examples) and systematically analyse plunge pool morphology and location. Previous observations of plunge pools have been sparse. Plunge pools are up to $1100 \mathrm{~m}$ wide and $75 \mathrm{~m}$ deep, with a mean diameter of $400 \mathrm{~m}$ and a mean depth of $21 \mathrm{~m}$. Plunge pools only occur where there are sharp decreases in slope of more than $4^{\circ}$, and are well developed where changes in slope exceed $15^{\circ}$. We propose plunge pools can be created by two mechanisms. Firstly, they may be due to reduced bed shear stress downstream of hydraulic jumps in submarine sediment-laden density flows that causes the deposition of bedload and the creation of a sediment bar. This bar then defines the downslope margin of a pool. Secondly, the impact of high-momentum sediment-laden density flows can excavate a depression, as has been observed for subaerial snow avalanches. Sediment deposited downslope of these impact pools is very poorly sorted, and partly derived from erosion within the pool. Both mechanisms influence whether turbidity currents are generated from high-density sediment-laden density flows, influence whether depositional flows are channelised, and have implications for base-of-slope facies models. (C) 2002 Elsevier Science B.V. All rights reserved.
\end{abstract}

Keywords: plunge pools; multibeam bathymetry; sediment-laden density flows; continental slope; morphology; hydraulic jump

\section{Introduction}

Submarine sediment-laden density flow deposits ${ }^{1}$ at the base of the continental slope are often attractive sites for hydrocarbon exploration. Pre-

* Corresponding author. Tel.: +44-117-9545403; Fax: $+44-117-9253385$.

E-mail address: simon.lee@bristol.ac.uk (S.E. Lee). dicting the geometry of such deposits is becoming increasingly important, as exploration occurs more frequently in deep-water settings beyond the modern shelf edge (Weimer and Slatt, 1999). Submarine sediment-laden density flows pose significant hazards to the foundations of structures placed in such deep waters, whilst their ability to destroy expensive sea-floor cables and pipelines has been amply demonstrated (e.g. Piper et al., 1988). The evolution of submarine sediment-laden 


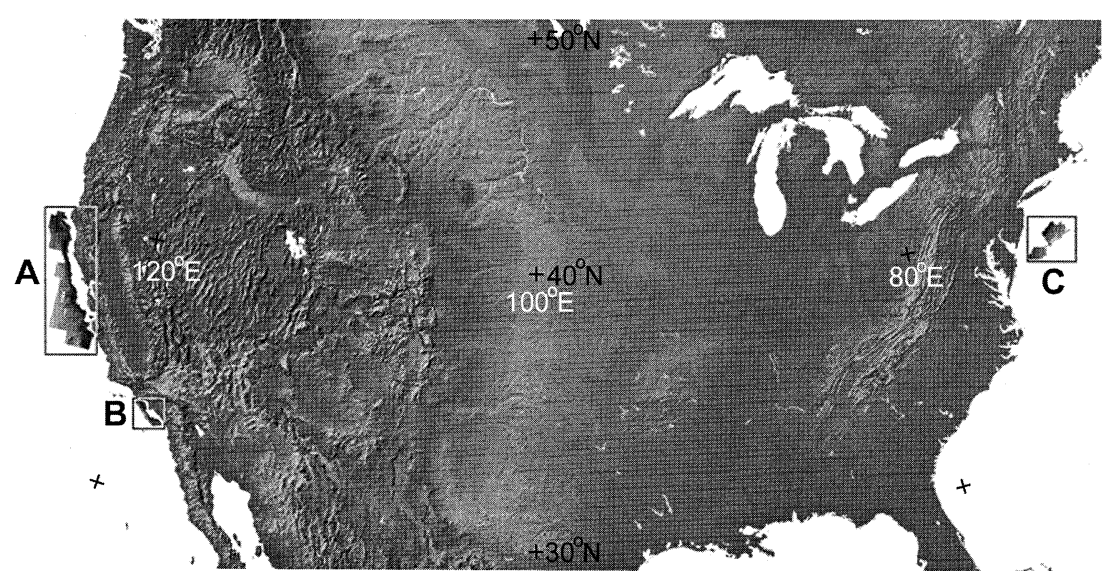

Fig. 1. Location map of the study areas. Studied areas are shown in boxes. Labelled areas are (A) Californian margin, (B) Los Angeles margin and (C) New Jersey margin. See Fig. 2 for a closer view of the Los Angeles margin. Image of the continental USA created by the US Geological Survey, EROS Data Center and the National Atlas of the United States. Bathymetry images added using data from USGS (Gardner et al., 1999). Shallower water depths are shown by darker shades.

density flows is poorly understood because of their transient nature and inaccessible location. Direct measurements of flow conditions are only available for a few relatively dilute turbidity currents in fjords, lakes and reservoirs (Middleton, 1993; Kneller and Buckee, 2000; Mulder and Alexander, 2001). Much of what we know about such flows is inferred from laboratory experiments (Middleton, 1993; Kneller and Buckee, 2000). Due to this lack of direct observations of submarine sediment-laden density flows we have drawn from the literature on snow avalanches and fjords in an effort to better understand the processes active on the continental slope. The morphology of the continental slope and rise is primarily sculpted by these submarine sediment-laden density flow events. High-resolution digital bathymetry has recently been made available for parts of the US Economic Exclusion Zone (Figs. 1 and 2;
Pratson and Haxby, 1996; Gardner et al., 1999). This geographically extensive data set provides a new opportunity to understand the dynamical evolution of submarine sediment-laden density flows through the morphologies they leave behind. A shallow linear depression is observed running along parts of the base of the continental slope off New Jersey and California. Detailed investigation showed that such depressions were made up of a series of discrete depressions for which we use the term 'plunge pool' (Fig. 3).

Using new data this work documents for the first time the widespread occurrence of plunge pools at the base of steep continental slopes. A synthesis of the morphological characteristics of plunge pools is presented in this paper. To highlight the geographical diversity of plunge pool localities and to elucidate processes of pool formation we include a comparison to previously

\footnotetext{
1 The term submarine sediment-laden density flow is used as a general term for an event that may comprise both, or either, a turbidity current and debris flow. At present, there is no consensus on the exact definition of 'turbidity current' and 'submarine debris flow' (see Mulder and Alexander, 2001; Kneller and Buckee, 2000 for recent reviews). The following brief definitions are adopted in this paper. A turbidity current is a relatively dilute flow from which larger particles progressively settle onto the bed, possibly into a higher-concentration traction layer. The deposits of such flows (turbidites) show evidence of progressive aggradation, such as vertical patterns of normal and inverse grading or stringer of outsize clasts along discrete horizons. Debris flows have higher sediment concentrations and significant cohesive or frictional yield strengths. They deposit sediment by en-masse 'freezing', potentially in a series of surges (Major, 1997), such that outsize clasts are chaotically arranged and clast-rich intervals have an abrupt upper boundary.
} 


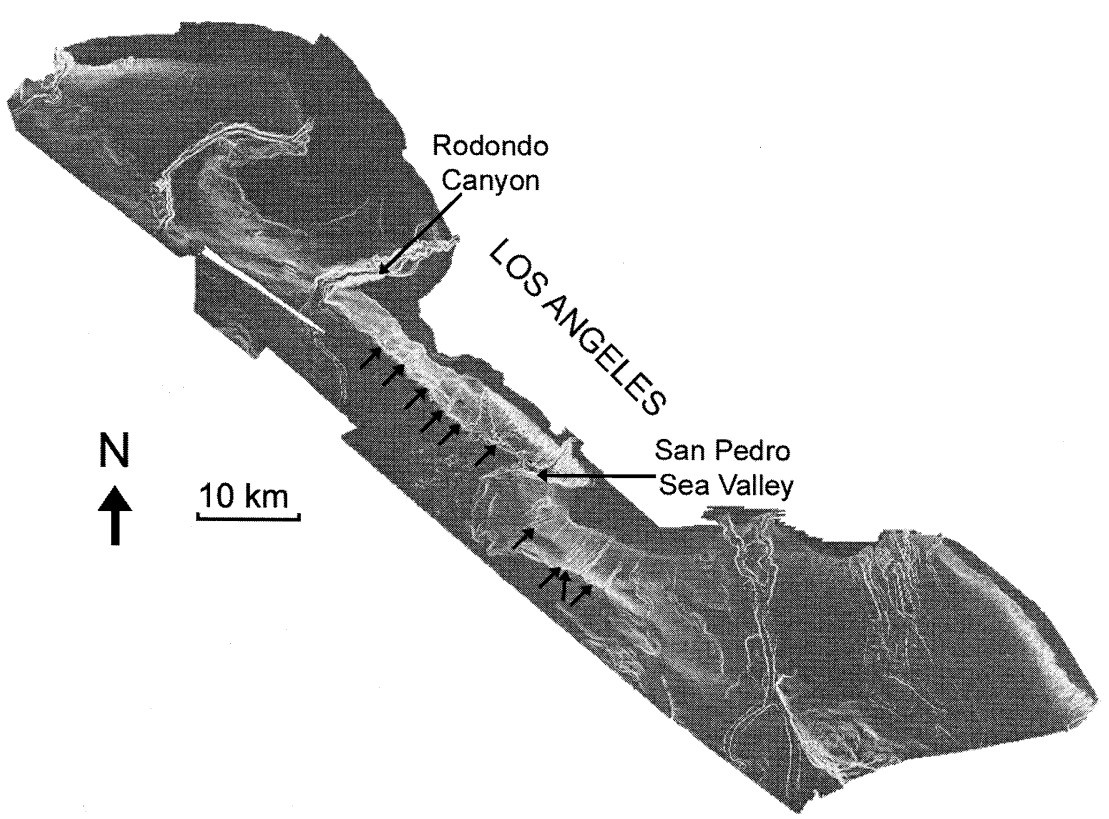

Fig. 2. Plan view slope map from the Los Angeles margin. Light shades are high slope values, dark shades are low slope values. Arrows indicate the locations of plunge pools. This example illustrates the correlation between large breaks in slope and the occurrence of plunge pools. Original data from USGS (Gardner et al., 1999).

reported isolated plunge pools at the base of steep submerged slopes. Processes capable of creating plunge pools at the base of the continental slope are briefly reviewed. Two models are presented for the creation of plunge pools: hydraulic jumps and impacts of submarine sediment-laden density flows. Evidence suggesting the mode of origin of the observed plunge pools is then discussed.

\section{Site locations}

Gridded bathymetry, made available by the US Geological Survey, was analysed for the continental slope and rise offshore from California and New Jersey (Figs. 1 and 2; Pratson and Haxby, 1996; Gardner et al., 1999). These locations represent contrasting plate tectonic settings. The tectonically active Californian margin is the site of a major transform plate boundary. The margin has a relatively narrow continental shelf $(<20 \mathrm{~km})$ that is indented by a series of large submarine canyons, some of which originate close to the coastline. The passive margin off New Jersey has a relatively wide $(\sim 120 \mathrm{~km})$ and lower gradient shelf. Canyons only occur on the continental slope in the New Jersey area. Partially buried canyons extend across the continental shelf in adjacent locations. During the last lowstand in sea level, deltas supplied large amounts of sediment to the upper parts of both continental slopes (Pratson et al., 1994).

\section{Methodology}

Two sets of high-resolution multibeam bathymetry from the USGS were examined. Initially, bathymetry with 100-m grid cells was used (Fig. 1; Pratson and Haxby, 1996). This work was then enhanced by a detailed analysis of higher-resolution bathymetry with horizontal resolution of 16 m (Fig. 2; Gardner et al., 1999) for a smaller part of the Californian margin offshore from Los Angeles. The accuracy of water depths, in both cases, is well within the International Hydrographic Organization standard of $1 \%$ of true water depth, and in most cases this accuracy is 


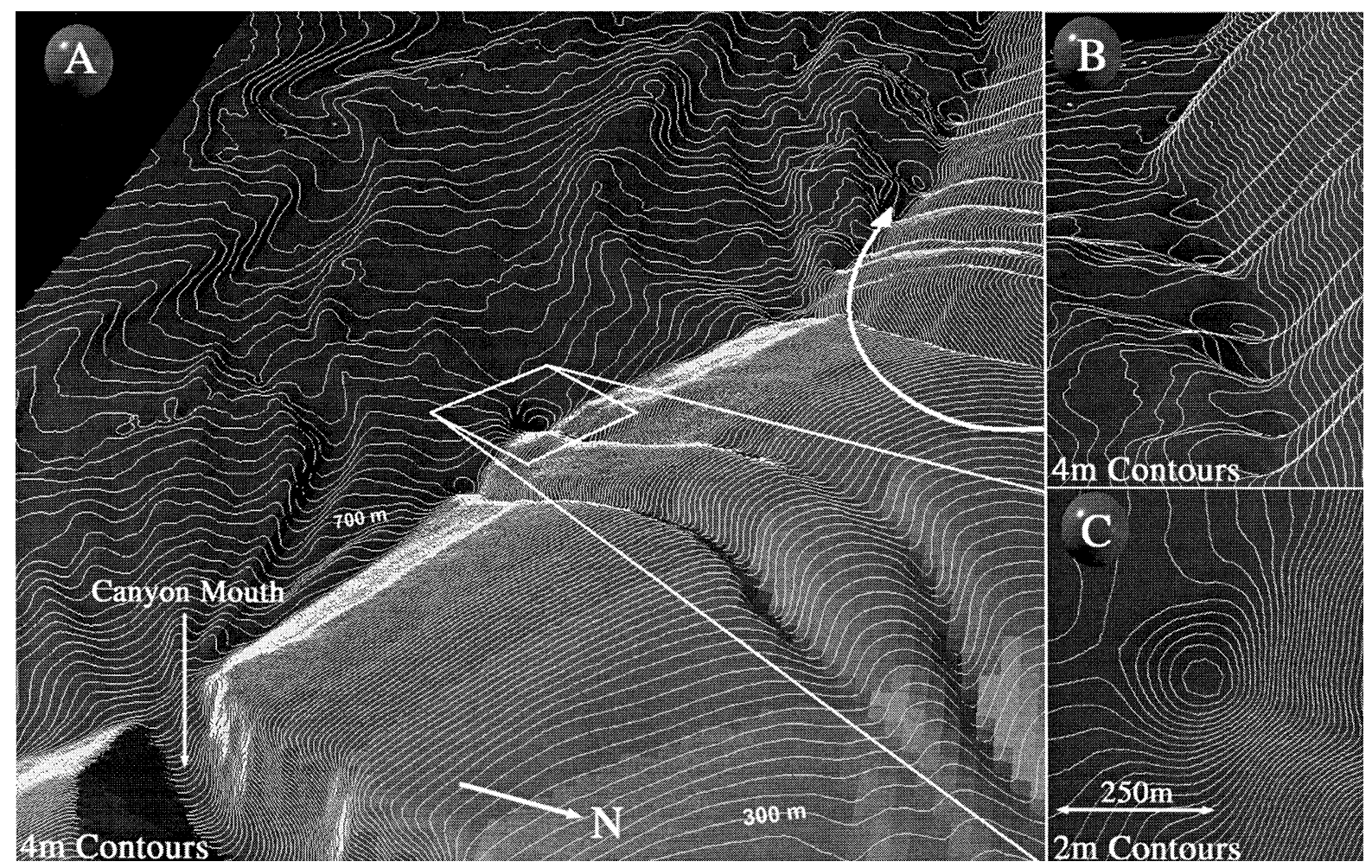

Fig. 3. (A) Three-dimensional perspective of the Los Angeles margin. The image is looking down the continental slope at a group of plunge pools. Note the lack of plunge pools at the low break in slope areas, for example at canyon mouths. The scene is given false-sun illumination from the southeast and has four times vertical exaggeration. The horizontal distance along the base of slope is approximately $5.4 \mathrm{~km}$ (bottom left to top right). (B) View west along the continental slope illustrating a grouping of plunge pools that create the impression of a linear depression at the base of slope in lower resolution data. (C) Plan view of a plunge pool. The pool is approximately $200 \mathrm{~m}$ in diameter. Original data from the USGS (Gardner et al., 1999).

better than $0.5 \%$ of true depth (Grim, 1992). Water depths in the vicinity of the plunge pools vary between $\sim 700 \mathrm{~m}$ and $3500 \mathrm{~m}$, giving a vertical resolution of $\sim 3.5-17.5 \mathrm{~m}$ in such settings. The water depth of each plunge pool was taken into account when deciding whether plunge pool depth exceeded the uncertainties in the bathymetric data. Only plunge pools with depths more than $0.5 \%$ of the water depth were included in the data base. The full extent of the data sets was examined, which included locations at the base of the continental slope with changes in slope that ranged from effectively zero to $30^{\circ}$.

The location and morphology of 150 pools were compiled (Figs. 3-10). This dataset excluded any pools located within a canyon and ambiguous cases which could be interpreted as the headscarp of slumps or other mass-wasting features. The ex- istence and morphology of upslope erosion features associated with the pools were also noted. Care was taken to reject any distinctive bathymetric artefacts, such as 'omega effects', arising from the process of bathymetric sounding, as described by de Moustier and Kleinrock (1986).

\section{Results}

\subsection{Dimensions}

An individual plunge pool consists of an ovoid depression on the downslope side of a break in slope (Figs. 3 and 4). Most pools have a subdued topographic rampart on their downslope side, which is often partly breached near its centre (Fig. 4). Pools are typically $\sim 400 \mathrm{~m}$ wide, with 

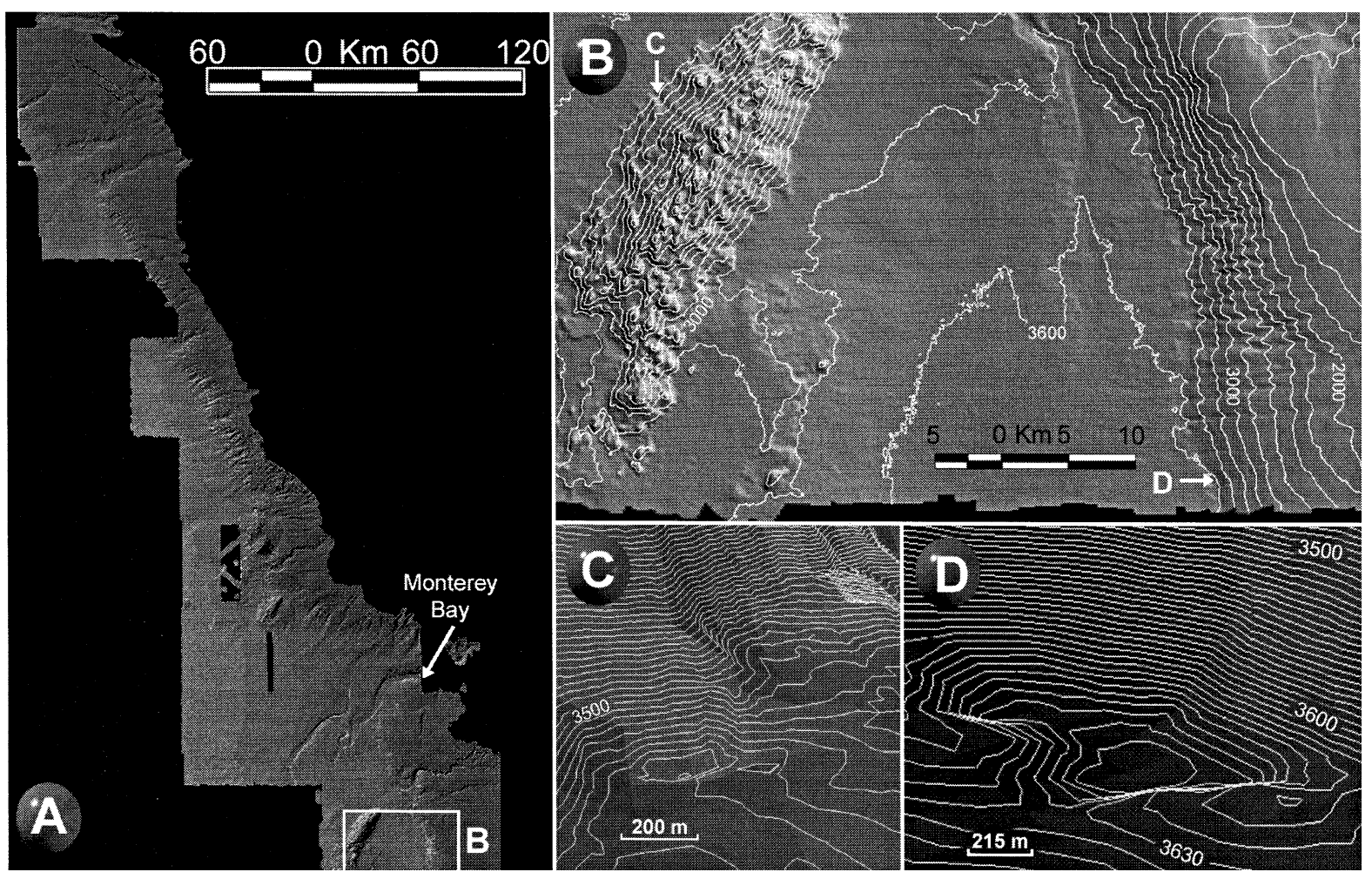

Fig. 4. Images of the Californian margin (A) and (B) showing plunge pools with an ovoid rampart (C) and an arcuate rampart (D). In D the arcuate rampart appears to have been breached at its centre. Scenes C and D have four times vertical exaggeration. Scenes are given false-sun illumination from northeast (B,C) and northwest (A,D). Contours are at $200 \mathrm{~m}$ intervals for (B) and $5 \mathrm{~m}$ intervals for (C) and (D). Original data from Pratson and Haxby (1996).

a mean pool depth of $21 \mathrm{~m}$. In the two study areas the widest pool is $1100 \mathrm{~m}$ in diameter and the greatest observed depth is $75 \mathrm{~m}$ (Fig. 5). The widths of the pools were measured parallel to and normal to the base of the continental slope. These measurements were used in order to determine if plunge pools are elongate in a direction orthogonal or parallel to slope break. The relationship shows considerable scatter $\left(r^{2}=0.32\right.$, Fig. 6A). The ratio of the slope normal to slope parallel diameter of the pools gives us an indication of the degree of circularity in plan view. Few pools have ratios of more than $5: 2$, or less than $2: 5$ (Fig. 6B). The probability distribution of the ratio is log-normal, with a median value very close to unity. A log-normal distribution often arises from multiplication of a number of randomly distributed parameters (Aitcheson and Brown, 1966). This log-normal distribution of ratios may indi- cate that several factors determine pool ratio in a multiplicative fashion. There is no correlation between the diameter ratio and the depth of the pool (Fig. 6C). A wide variation is observed in

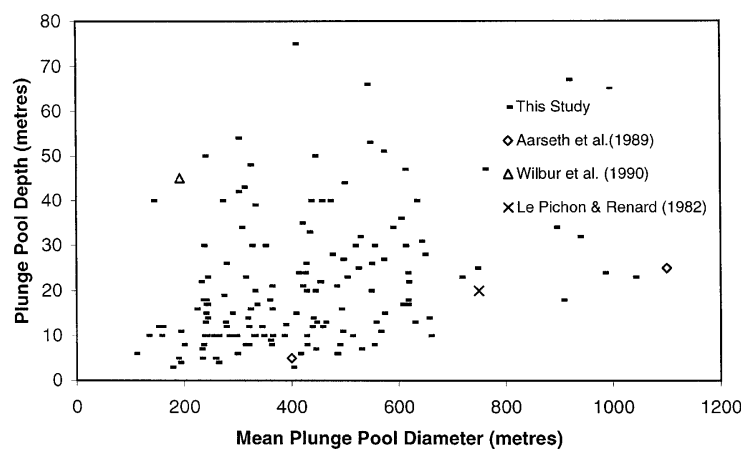

Fig. 5. Dimension range of plunge pools observed by this study and previous publications (Aarseth et al., 1989; Wilber et al., 1990; Le Pichon and Renard, 1982). 

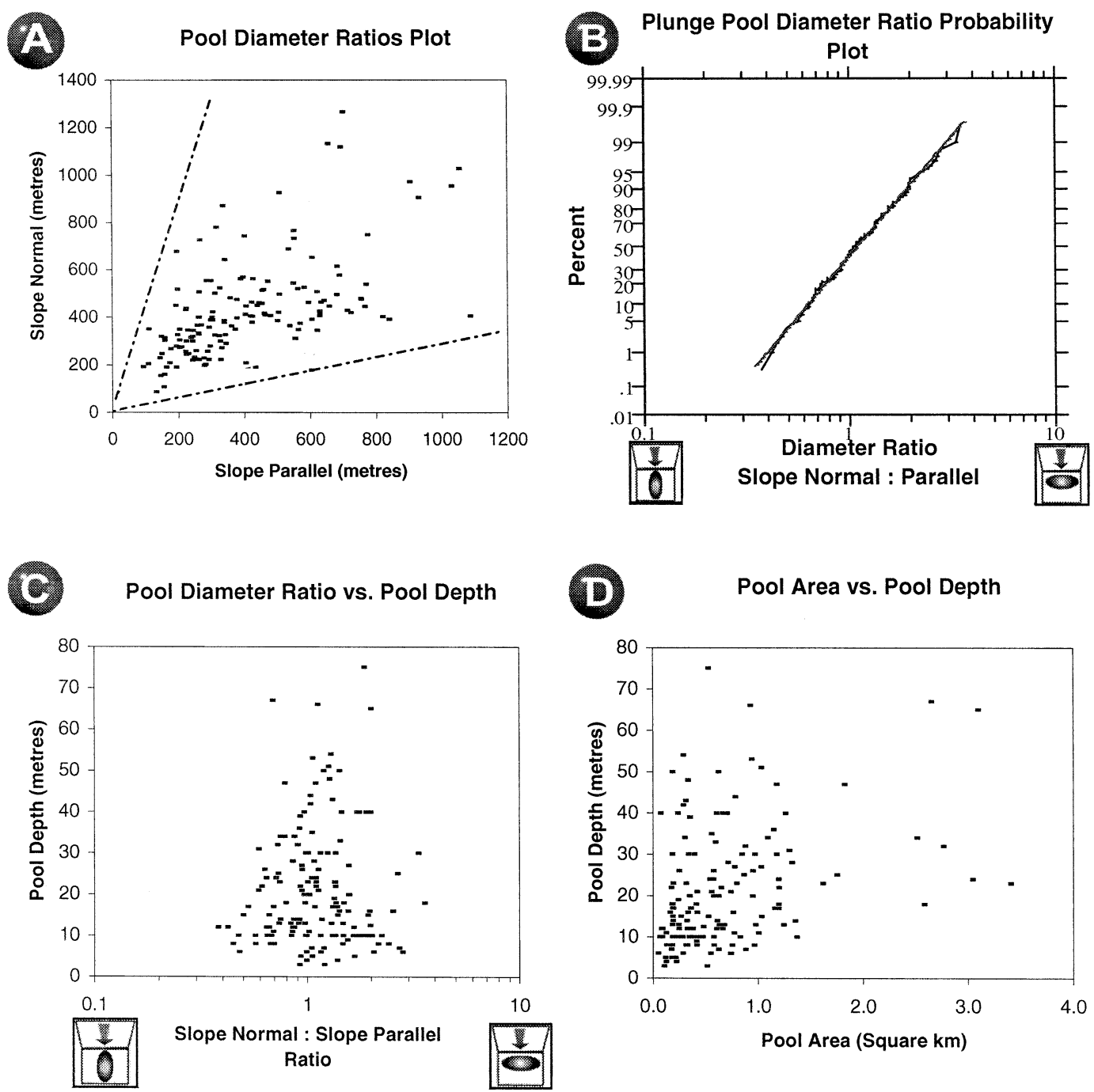

Fig. 6. Planform shape of plunge pools. (A) Plunge pool diameter measured normal to, and parallel to, the local base of the continental slope $\left(r^{2}=0.333\right)$. (B) Probability distribution graph of plunge pool diameters. Ratios of less than one are elongate parallel to the slope; more than one are elongate normal to the slope; one is circular. Inset diagrams are graphical representations of pool shape. The trendline has a correlation coefficient $\left(r^{2}\right)$ of 0.995 . (C) Pool depth is plotted against the ratio of the pools' diameters normal and parallel to the slope. No trend is observed $\left(r^{2}=0.004\right)$. Inset diagrams are graphical representations of pool shape. (D) The area of the pool in planform is plotted against the depth of the pool to investigate links between the two dimensions $\left(r^{2}=0.170\right)$

the relationship of the area of a plunge pool in planform and the depth of the pool (Fig. 6D).

\subsection{Rampart morphologies}

In planform, plunge pool ramparts may be ovoid ( $40 \%$ of cases) or arcuate $(60 \%$ of cases).
Arcuate ramparts often ( $\sim 25 \%$ of population) appear to have their centre breached (Fig. 4). This breach may indicate that the pool was formed by multiple flows, with later, more erosive flows cutting through the rampart and creating the breach. In some cases the rampart is not visible. This suggests that the flow has retained 


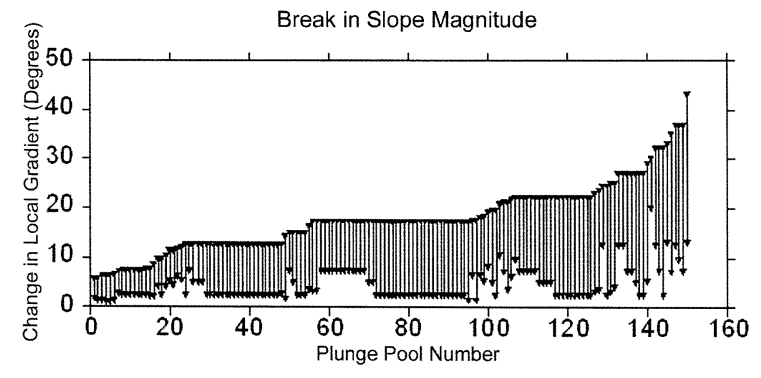

Fig. 7. Magnitude of local break in slope at plunge pools, measured over a horizontal distance of less than $250 \mathrm{~m}$, at the base of the New Jersey and Californian continental slopes. The top of the arrow indicates the scarp gradient proximal to the pool (within the feeder gully if present). The bottom of the arrow indicates the slope gradient of the plain the plunge pool is located within.

enough energy to transport the sediment further and dispersed it as a thin sheet, has been masked by sediment draping or is simply below the resolution of the bathymetry.

\subsection{Break in slope}

A substantial break in slope is necessary for plunge pool formation. Pools were not observed where the break in slope is less than $4.2^{\circ}(73 \mathrm{~m}$ $\mathrm{km}^{-1}$; Figs. 2, 3, 7 and 8). Over $80 \%$ of pools were associated with a break in slope of over $9.8^{\circ}\left(170 \mathrm{~m} \mathrm{~km}^{-1}\right)$. Plunge pool population density is highest in areas characterised by high breaks in slope as illustrated by the continental slope offshore of Los Angeles (Fig. 2). In this area, slopes abruptly decrease from $\sim 20^{\circ}(350 \mathrm{~m}$ $\left.\mathrm{km}^{-1}\right)$ to $\sim 5^{\circ}\left(87 \mathrm{~m} \mathrm{~km}^{-1}\right)$. Due to relative infrequency of data for high slope angles (Fig. $8 \mathrm{~B}, \mathrm{C})$ it is not possible to determine if there is indeed a relationship between the slope angle(s) and the circularity of a plunge pool. There is no clear correlation between the magnitude of the break in slope and plunge pool diameter (Fig. $8 \mathrm{D}, \mathrm{E})$.

\subsection{Influence of the continental slope on submarine plunge pools}

The relationship between incisional features on the continental slope (for which we use gully as a general term) and plunge pool average diameter and depth parameters are briefly examined. Due to the bulk of the bathymetric data having a horizontal resolution of $100 \mathrm{~m}$, gullies below this resolution would not be visible, thus a set of data from the 16-m horizontal-resolution bathymetry was used to examine the influence of gully runout and change in gully elevation. Gully runout is defined as the hypotenuse of a triangle, where horizontal extent is one side and the depth difference between the start and end of the gully as the second side of the triangle. The change in gully elevation is defined as the bathymetric depth at the base of the continental slope minus the bathymetric depth at the top of the continental slope. These high-resolution data show no trends for the parameters examined (Fig. 9A-D).

\subsection{Tectonic influence}

The Californian and New Jersey margins have contrasting tectonic settings comprising an active transform boundary and a passive margin. As plunge pools are found on both margins, tectonic setting is not a limiting factor.

\section{Mechanisms for submarine plunge pool formation}

Two mechanisms are proposed for the formation of plunge pools at sharp changes in gradient, such as those observed in this study at the base of the continental slope. These two mechanisms are hydraulic jumps and the impact of high-momentum flows. The mechanisms are not mutually exclusive. The observation that plunge pools only occur at sharp breaks in slope, and the evidence for slope failure above many of the pools (similar in morphology to the chutes of Farre and Ryan, 1985) suggest they are created by sediment flows originating on the continental slope.

Along-contour flows (which deposit contourites) are unlikely to be the cause of submarine plunge pools. Plunge pools are generally narrower than depressions created by contourite deposition, and comprise a series of discrete depressions rather than the elongate trough formed by along- 
Break in Slope vs. Plunge Pool Depth

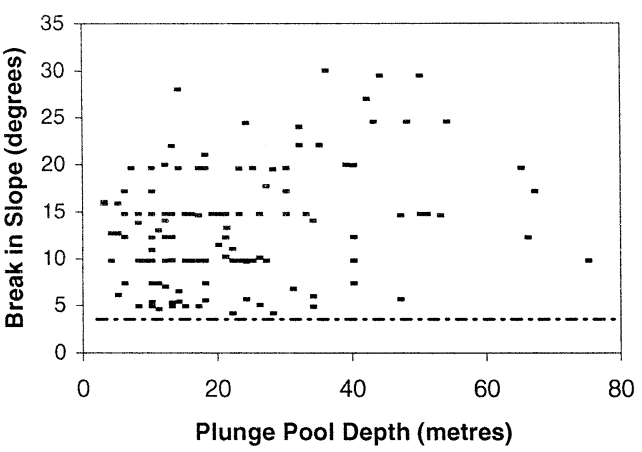

16

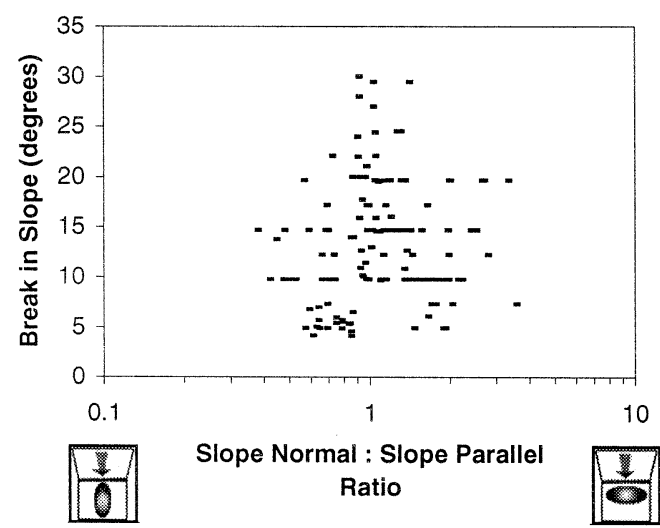

$=$

Break in Slope vs. Average Pool Diameter

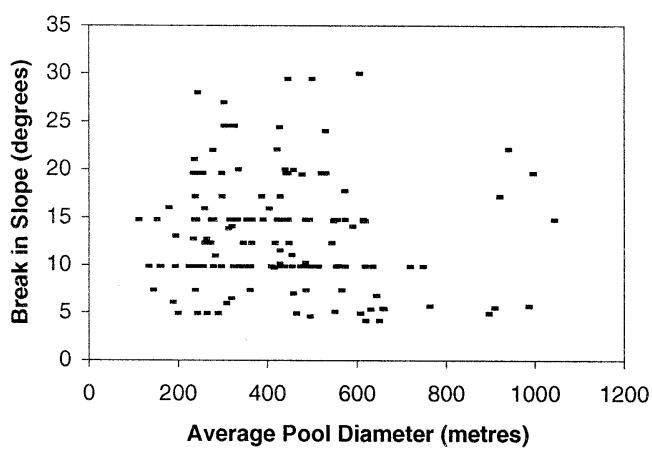

$=$ Slope Above Pool vs. Diameter Ratio

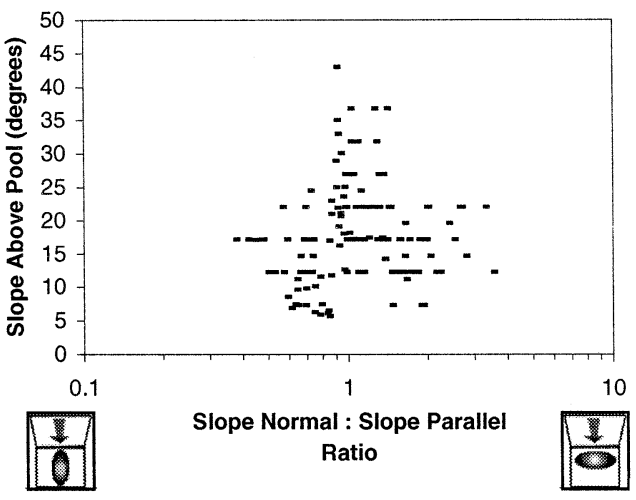

D) Break in Slope vs. Greatest Diameter of Pool

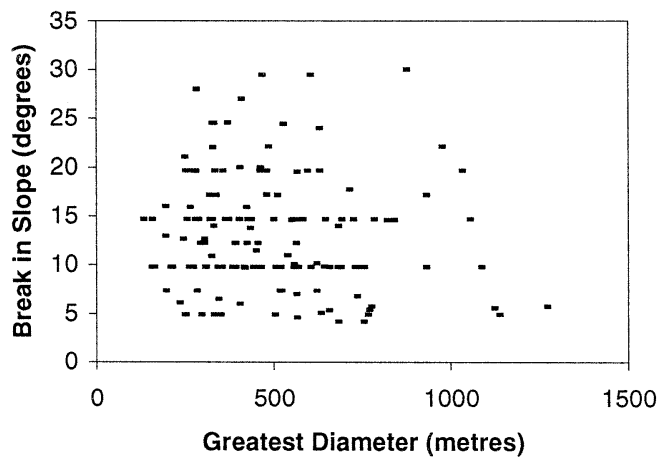


Fig. 8. Plots illustrating the relationship between the break in slope and other morphological parameters. (A) The break in slope plays an important role, as a minimum local slope change of $4.2^{\circ}$ is needed for plunge pool formation $\left(r^{2}=0.074\right)$. (B) The distribution of pool diameter ratio to slope values is illustrated. A lack of data at higher scarp slope angles and break in slope values make interpretation difficult $\left(r^{2}=0.018\right)$. Inset diagrams are graphical representations of pool shape. (C) Relationship of pool diameter ratio to the magnitude of local break in slope. No trend can be assigned $\left(r^{2}=0.018\right)$. Inset diagrams are graphical representations of pool shape. (D,E) The relationship of break in slope to average and maximum pool diameter is illustrated. No trend is observed $\left[r^{2}=0.027(\mathrm{D})\right.$ and $\left.0.022(\mathrm{E})\right]$.
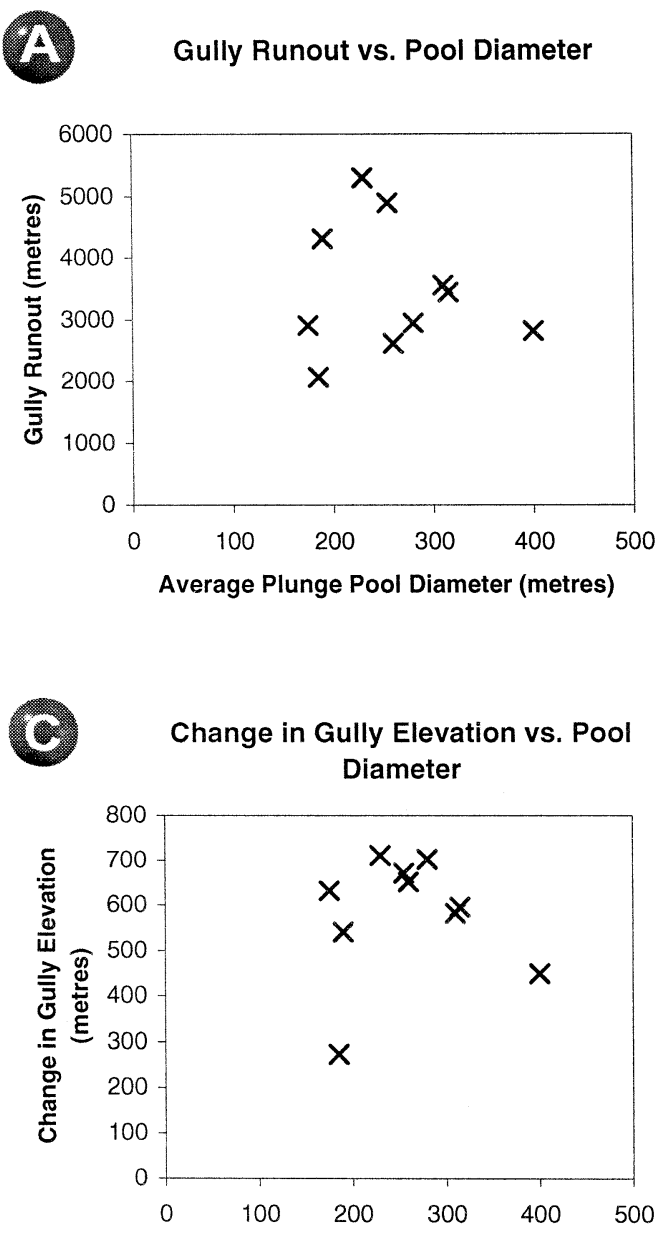

Average Plunge Pool Diameter (metres)
1 Gully Runout vs. Plunge Pool Depth

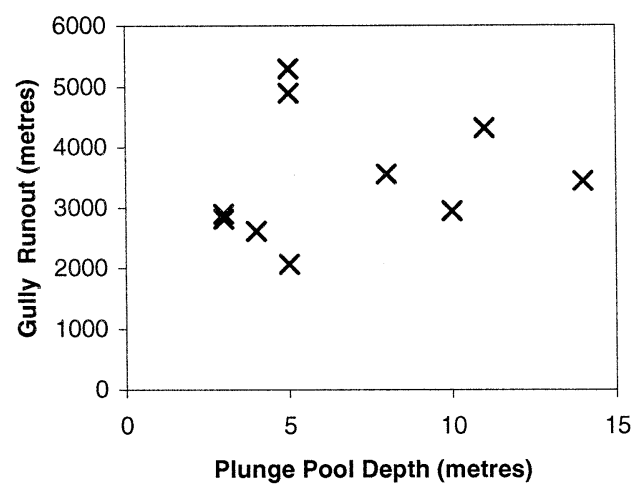

Dotential Energy Proxy vs. Plunge Pool
Depth

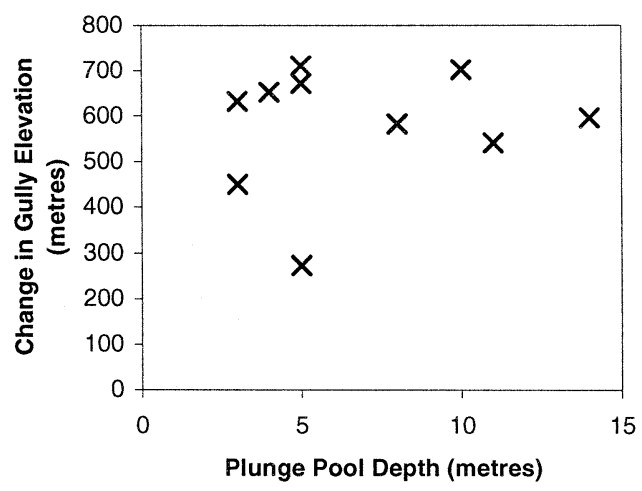

Fig. 9. Analysis of data from the Los Angeles margin, with a horizontal resolution of $16 \mathrm{~m}$. This high resolution allows gullies located upslope of the pools to be confidently located. (A,B) Gully runout was calculated as the hypotenuse of the altitude drop of the gully linked to the plunge pool and the horizontal length of the gully. (C,D) Change in altitude of the gully is used as a potential energy proxy. No trend is observed between this parameter and pool dimensions $\left[r^{2}\right.$ values: (A) 0.010 , (B) 0.071 , (C) 0.030 and (D) 0.026]. 


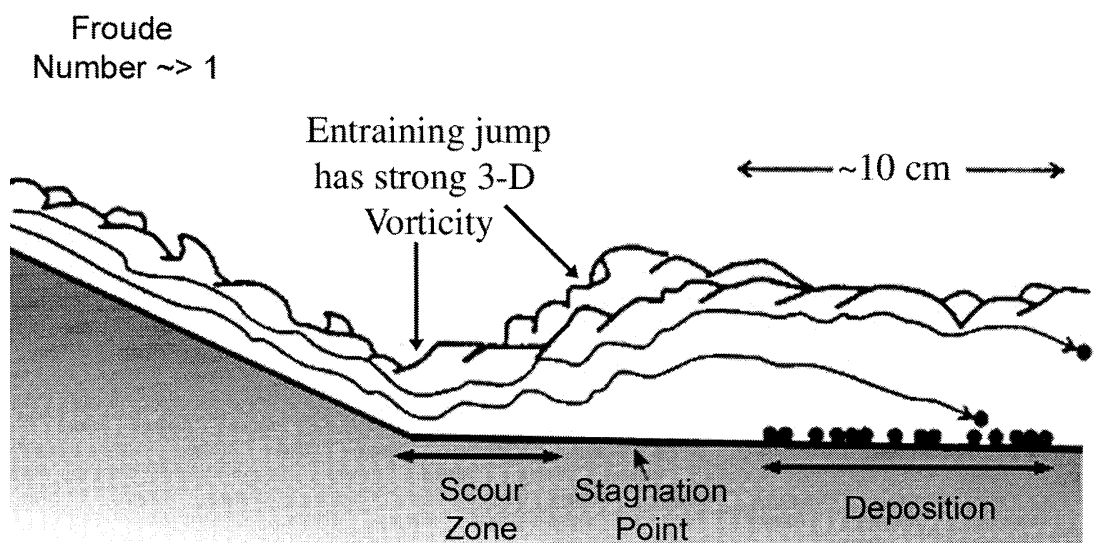

Fig. 10. Laboratory experiments on the effects of a hydraulic jump (at a break in slope) illustrating patterns of particle erosion and deposition. Note the scour at the base of slope and downstream deposition of particles. In this case the densiometric Froude number ( $\mathrm{Fr}$ ) is used, defining subcritical flows as $\mathrm{Fr}<1$, and supercritical flows as $\mathrm{Fr}>1$. Upper slope values ranged from $5^{\circ}$ to $40^{\circ}$ with unit initial flow rates from 1 to $6.5 \mathrm{~cm}^{2} \mathrm{~s}^{-1}$. After Macías et al. (1998).

contour flows (Viana et al., 1998; Stow et al., 1998). The location of plunge pools below gullies on the continental slope reinforces the view they are not formed by along-contour currents.

Depressions on the sea floor have also been reported on the continental rise away from the break in slope, where changes in slope are relatively subdued (e.g. Shor et al., 1990), and on levees of submarine channels (Normark and Piper, 1991). Pools in these locations are not considered herein.

\subsection{Hydraulic jumps ('hydraulic jump pools')}

Submarine gravity-driven flows may display either supercritical (shallow and fast) or subcritical (deep and slow) flow regimes (Komar, 1975). An abrupt transition from the former (densiometric Froude number $>1$ ) to the latter (densiometric Froude number $<1$ ) occurs through a submerged hydraulic jump. There is a critical change in slope, for given magnitudes of flow depth, density and frictional forces, at which the hydraulic jump will occur. Estimates of this change in critical slope for turbidity currents range from $\sim 1$ to $20 \mathrm{~m}$ $\mathrm{km}^{-1}$ (e.g. Komar, 1971, 1975), with disagreement reflecting different estimates of the initial flow densities and friction factors, whose range of values is poorly constrained by field observation. This range of slopes associated with the transition of flow regime was often observed at the base of continental slopes. As noted by Middleton (1993), "In turbidity current systems, hydraulic jumps must take place at the base of slope, and should produce important - though presently largely unrecognised - geomorphological and sedimentological effects". Debris flows can also undergo hydraulic jumps (Weirich, 1988, 1989). Theoretical and experimental modelling suggests that submerged hydraulic jumps will cover distances of $1 \mathrm{~km}$ or less (Komar, 1971). Such distances are comparable to the diameters of the plunge pools observed in this study.

Bed shear stress can be significantly reduced downstream of a hydraulic jump, as mean flow velocities become slower (Komar, 1971; Garcia and Parker, 1989). The magnitude of the reduction is related to the change in the densiometric Froude number (Komar, 1971). The flow's level of turbulence at a hydraulic jump is related to the magnitude of the change in the densiometric Froude number as the flow passes from a supercritical to a subcritical regime. Larger-magnitude breaks in slope, which result in greater reduction of flow velocity, will increase the likelihood of flow scouring. This may explain why we only observe plunge pools at high breaks in slope. As shown experimentally by Jopling and Richardson (1966) for shallow open-channel flows, and by Garcia (1993) for submerged particulate gravity 
currents, this decrease in bed shear stress leads to rapid deposition of coarser bedload in the vicinity of the jump.

Macías et al. (1998) present an informative study of how saline density currents interact with a sharp break in slope. Particles were seeded within the saline currents to visualise patterns of deposition. For initially supercritical flows a hydraulic jump formed with strong three-dimensional vorticity. A sheet of coarse sediment was deposited downstream of the jump (Fig. 10). If the initial flow was subcritical no hydraulic jump occurred, but a two-dimensional roller wave was observed at the slope break. Flow recirculation caused sediment deposition at the slope break, either as the bedload encountered flow stagnation or through sweeping of bedload through the recirculating eddy. Sedimentation prograded upstream. Realistic erosion of the flume's Perspex bed cannot occur in these experiments, making an assessment of patterns of erosion problematic. Lack of deposition suggests erosion would occur immediately downstream of the break in slope in the case of a hydraulic jump (Macías et al., 1998).

\subsection{Impact by high-momentum flows ('impact pools')}

Subaerial snow avalanches have been observed to form pools with constructional ramparts when they encounter a sharp decrease in slope (e.g. Smith et al., 1994). These flows have sufficient momentum to generate a downward-directed force which erodes material to form an impact pool. Eroded material is deposited, together with material derived from much further upslope, to create a raised embankment of chaotically bedded and poorly sorted soil and rock. This embankment tends to be highest downstream of the centre of the pool (Smith et al., 1994). Observed snow avalanche pools are 10-100 m wide and up to $\sim 20 \mathrm{~m}$ deep. Slopes of the avalanche tracks above the pools are typically greater than $20^{\circ}$ (342 m km$~^{-1}$ ), whilst slopes are near-horizontal in the vicinity of the pools. Fig. 11 compares snow avalanche profiles with submarine plunge pools. Field studies show that individual snow avalanche pools are progressively sculpted by multiple avalanche events (e.g. Smith et al., 1994; Matthews and McCarroll, 1994). The pools often intercept the local water table and form small tarns. It has been suggested that the presence of water within the pool increases the shock on the substrate during avalanche impacts (Liestøl, 1974). This situation is similar to the front created by a submarine flow as it displaces ambient water from its path (Pratson et al., 2001). The peak pressure involved in scouring snow avalanche impact pools is approximately proportional to the product of flow density and the square of
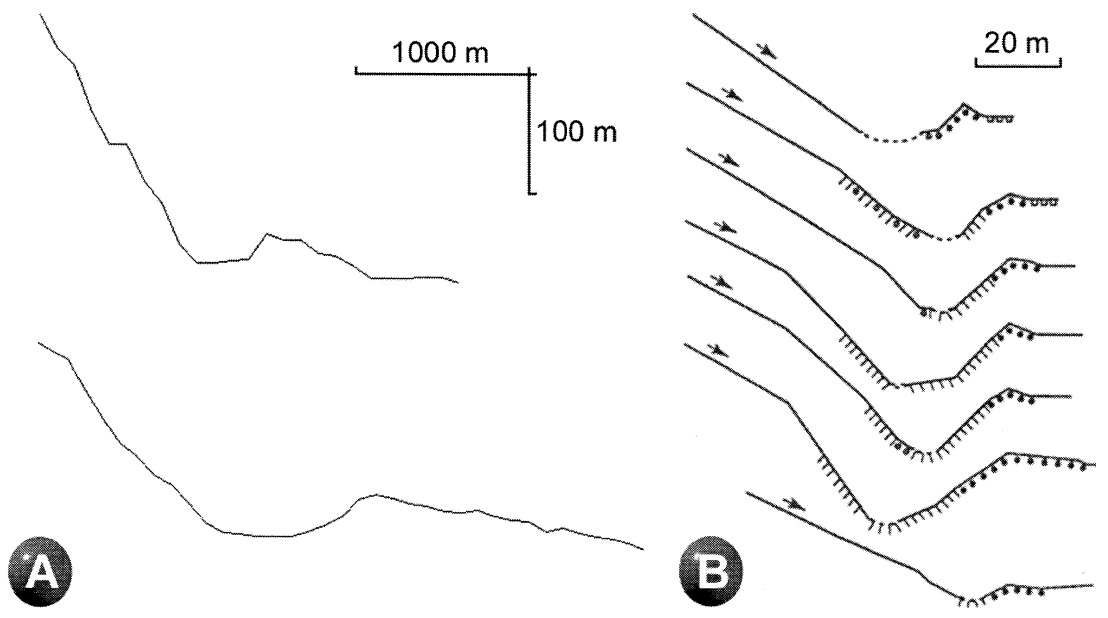

Fig. 11. Comparison of (A) submarine plunge pool and (B) snow avalanche impact pool profiles. Snow avalanche profiles have no vertical exaggeration. Snow avalanche impact pool profiles after Matthews and McCarroll (1994). 
flow velocity (Smith et al., 1994). Snow avalanches have densities of $50-400 \mathrm{~kg} \mathrm{~m}^{-3}$ (Hopfinger, 1983). Turbidity currents have densities of $\sim 1060-1140 \mathrm{~kg} \mathrm{~m}^{-3}$ (van Tassel, 1981). In the case of high sediment concentration submarine flows or slides densities can be up to $\sim 2000$ $\mathrm{kg} \mathrm{m}^{-3}$ (Elverhøi et al., 1997). The density of the fluid medium the flow is travelling through must be accounted for. For snow avalanches this is air and can be assumed to be negligible. For submarine flows the density of seawater is $\sim 1028 \mathrm{~kg}$ $\mathrm{m}^{-3}$. The effective density for turbidity currents is therefore $\sim 32-112 \mathrm{~kg} \mathrm{~m}^{-3}$. For high sediment concentration flows or slides the upper limit for effective density is $\sim 972 \mathrm{~kg} \mathrm{~m}^{-3}$. Snow avalanche densities are approximately two to four times those of turbidity currents and $0.05-0.4$ the density of high-concentration sediment flows or slides. Snow avalanche velocities of $60-85 \mathrm{~m} \mathrm{~s}^{-1}$ estimated by Smith et al. (1994) are three to four times those that have been estimated for fast submarine sediment-laden density flows $\left(\sim 20 \mathrm{~m} \mathrm{~s}^{-1}\right.$; Piper et al., 1988) on $\sim 5^{\circ}$ slopes. Submarine sediment-laden density flows on slopes significantly greater than $5^{\circ}$ (as frequently documented in this study) may indeed have higher velocities that have not yet been measured. This suggests that the impact pressure associated with turbidity currents is at least 0.01 and possibly up to 0.16 that of snow avalanches. The impact pressures associated with denser submarine sediment-laden flows are one-seventh to twice the pressure of snow avalanches. The impact pressures of denser submarine sediment-laden density flows and snow avalanches may be of comparable magnitude. Hydroplaning may significantly increase the velocity of submarine flows (Mohrig et al., 1998), potentially increasing the pressure associated with a flow's interaction with the seafloor at a break in slope. The crude calculations presented here use depth-averaged velocities and densities. Depthaveraged velocities and densities have been used in previous work to calculate snow avalanche impact pressures (Smith et al., 1994). Density and velocity stratification within the flow may produce localised variations in impact pressure. However, such localised variations cannot be constrained using available data from natural submarine flows. Submarine sediment-laden density flows will need to be wider, more frequent or more prolonged than snow avalanches to generate the significantly wider plunge pools seen in this study.

\section{Discussion}

Although previous studies, from a variety of settings, have noted the presence of individual plunge pools, this is the first demonstration of their regional occurrence and characteristic morphology. It is apparent that plunge pools occur where there is an abrupt decrease in slope of more than $\sim 4^{\circ}$ (they occur more frequently where the decrease is more than $\sim 10^{\circ}$ ), and are typically $\sim 400 \mathrm{~m}$ wide and $\sim 21 \mathrm{~m}$ deep. Plunge pools occur on both active and passive continental margins. Thus frequent seismic events do not appear to be necessary for their formation.

The process models based on hydraulic jumps and impacts are proposed as the processes by which submarine plunge pools form. These two processes are not mutually exclusive and either process may be dominant at different times in a plunge pool's history. Further investigation of surface and subsurface architecture of plunge pools on the sea floor is needed using precisely located seismic reflection profiles, side-scan sonar, submersible observations, and borehole data.

Numerical modelling of Pratson et al. (2001) examines the interaction between submarine sediment-laden density flows and a break in slope. Pratson et al. (2001) model debris flows as a Bingham plastic not permitted to erode the substrate. This latter constraint is justified by reference to small-scale flume experiments and may not hold for all submarine debris flows. For example, Gee et al. (1999) document significant proximal erosion by the extensive Saharan debris flow offshore from West Africa. Deposition by debris flows within Pratson et al.'s model can create a depression at the slope break. Debris flows thickens at the break in slope, as the tail catches up with the head, and the flow thickness needed to exceed the yield strength of the flow increases. The deposit thickens markedly in a short distance downslope of the break in slope, creating a subdued topo- 


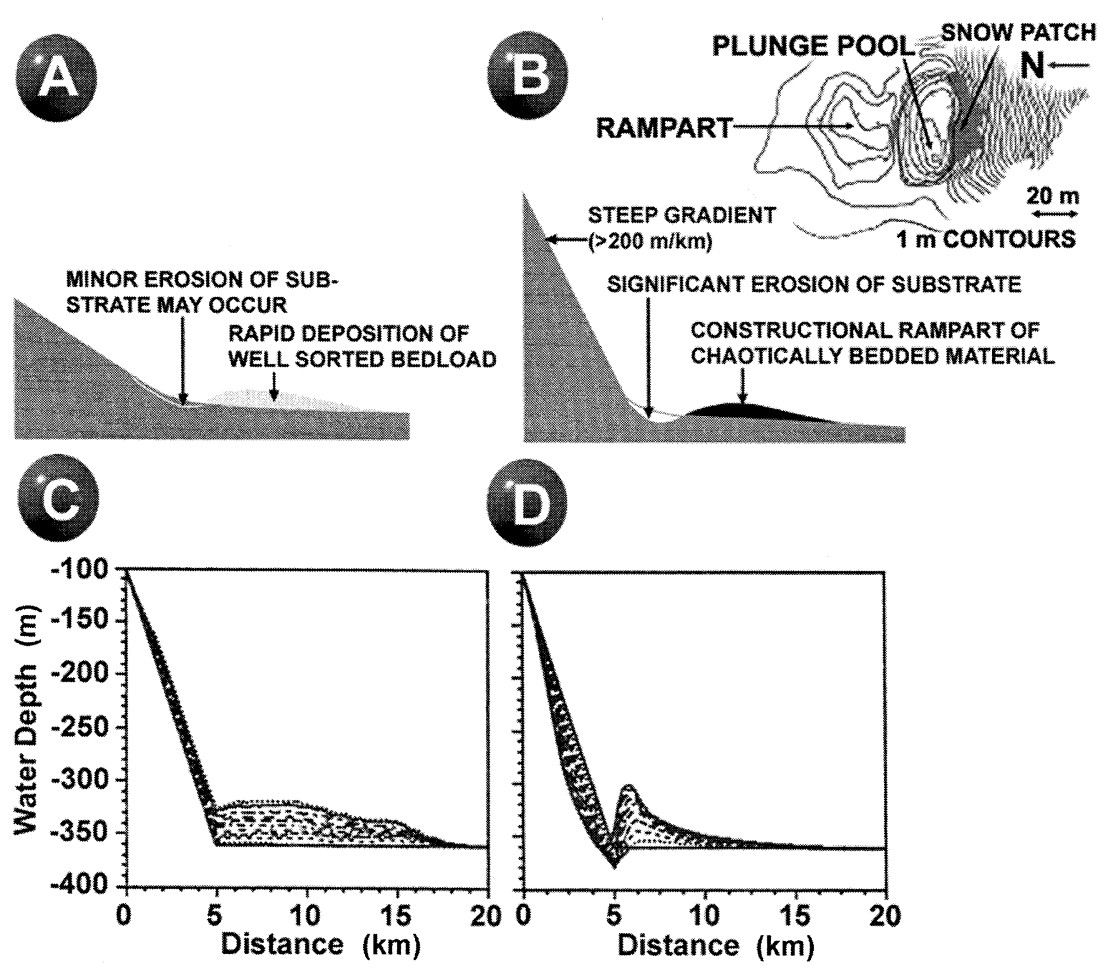

Fig. 12. Two mechanisms proposed for submarine plunge pool formation. Different erosional and depositional features, characteristic to each type of pool, are inferred from previous experimental work (e.g. Jopling and Richardson, 1966; Garcia, 1993; Garcia and Parker, 1989) and studies of naturally occurring plunge pools in fjords (Aarseth et al., 1989). (A) Hydraulic jump pool. A hydraulic jump occurs due to an abrupt reduction in sea-floor slope. The reduction of shear stress downstream of the hydraulic jump causes bedload deposition, whilst erosion occurs due to increased turbulence in the vicinity of the jump. (B) Impact pool. These occur at the base of steep continental slopes. The impact excavates a depression by eroding the substrate. Eroded material is deposited in downslope locations as either a sheet or a constructional rampart. The impact pool model is partly based on an analogy with snow avalanche impact pools. A snow avalanche impact pool observed at Geikkie Creek is shown in the inset, with 1-m contours (after Smith et al., 1994). (C,D) Results of numerical modelling of multiple turbidity currents and submarine debris flows by Pratson et al. (2001). Deposition of stacked debris flows (C) and turbidites (D) creates a depression ('erosional overshoot pool') at the slope break.

graphic depression. Deposition from repeated debris flows accentuates this depression (Fig. 12C). In Pratson et al.'s model turbidity currents are permitted to erode into the substrate, with erosion rates calculated using an energy budget. Energy not expended in overcoming friction, keeping sediment in suspension and entraining water, is used to erode sediment. Two-dimensional model runs with turbidity currents create a pronounced depression at a sharp change from an inclined slope $\left(1.5-5.25^{\circ}\right)$ to a horizontal surface (Fig. 12D). These currents emerge from the inclined slope with sufficient energy to erode into the initial part of the horizontal surface. The flows rap- idly slow and start depositing sediment. This abrupt transition from erosion to deposition creates a topographic depression. Subsequent turbidity currents encounter an even more marked change (or reversal) in slope and undergo the same abrupt transition from erosion to deposition. Thus, the depression becomes progressively accentuated. Deposits prograde into the pool from the down-dip side, and the pool migrates up-dip.

Pratson et al.'s (2001) results are intriguing. As with any numerical model, the sedimentary system is simplified significantly (e.g. the flow cannot expand orthogonally to the slope). The constraint 
that debris flows can never erode may be unrealistic for steep continental slopes. However, the general principles the model illustrates seem valid; (i) that a flow exiting the continental slope with sufficient energy may erode for a short distance into the continental rise as it decelerates and before it becomes depositional, (ii) purely depositional flows can create topographic pools through rapid changes in deposit thickness, and (iii) subsequent flow events can further accentuate the topographic depression. The way in which impact pools are created is related to the first principle, whilst hydraulic jump pools are created experimentally solely through deposition.

\section{Implications for facies models}

Determining the frequency and location of hydraulic jumps and flow impacts has important implications for base-of-slope facies models. Progradation of the continental slope and the associated movement of the plunge pool(s) location may generate an unconformity. Alternatively, progressive aggradation on the downslope margin of the plunge pool may cause sediment to onlap the continental slope, as illustrated by Pratson et al. (2001) using the seismic reflection profile of Poag and Mountain (1987) across the base of the New Jersey slope. Continental slope profiles, and the magnitude of palaeo-slope breaks, can be approximated from seismic reflection profiles (e.g. Fulthorpe and Austin, 1998). These data, together with the necessary information on the break in slope documented by this study, may allow the location of plunge pools to be predicted in subsurface prograding-slope sequences. The occurrence of hydraulic jumps and impact events also has important implications for sediment deposition further downslope. These mechanism have the potential to create dilute turbidity currents from denser sediment-laden density flows (e.g. Mohrig et al., 1998), although Komar (1971) suggested that dilution due to hydraulic jumps would be minimal. Both mechanisms have significant implications for whether submarine sediment-laden density flows become channelised on lower gradient slopes (see Imran and Parker, 1998). In par- ticular, flow impacts may prevent the downslope development of channelised currents.

\section{Acknowledgements}

The authors thank Bill Virden and Bill Haxby for answering queries concerning the bathymetric data. Gary Parker, Lincoln Pratson, Jasim Imran, James Syvitski and Eric Hutton are thanked for pre-prints of their papers on numerical modelling of density flows. We would like to thank Kevin Schofield and Roy Fitzsimmons of Conoco Inc. Conoco sponsored Simon Lee's PhD, of which this work forms part. Marcus Bursik, Thierry Mulder, James Syvitski and David Piper are thanked for constructive comments on the paper.

\section{References}

Aarseth, I., Lonne, O., Giskeodegaard, O., 1989. Submarine slides in glaciomarine sediments in some western Norwegian fjords. Mar. Geol. 88, 1-21.

Aitcheson, J., Brown, J.A.C., 1966. The log-normal distribution with special reference to its uses in economics. Cambridge University Press, Cambridge.

de Moustier, C., Kleinrock, M.C., 1986. Bathymetric artifacts in seabeam data: How to recognise them and what causes them. J. Geophys. Res. 91 (B3), 3407-3424.

Elverhøi, A., Norem, H., Andersen, E.S., Dowdeswell, J.A., Fossen, I., Haflidason, H., Kenyon, N.H., Laberg, J.S., King, E.L., Sejrup, H.P., Solheim, A., Vorren, T., 1997. On the origin and flow behavior of submarine slides on deep-sea fans along the Norwegian-Barents Sea continental margin. Geomar. Lett. 17, 119-125.

Farre, J.A., Ryan, W.B., 1985. Three-dimensional view of erosional scars on the US Mid-Atlantic continental margin. Assoc. Am. Pet. Geol. Bull. 69, 923-932.

Fulthorpe, C.S., Austin, J.A., 1998. Anatomy of rapid margin progradation: Three-dimensional geometries of Miocene clinoforms, New Jersey margin. Assoc. Am. Pet. Geol. Bull. 82, 251-273.

Garcia, M., Parker, G., 1989. Experiments on hydraulic jumps in turbidity currents near a canyon-fan transition. Science 245, 393-396.

Garcia, M.H., 1993. Hydraulic jumps in sediment-driven bottom currents. J. Hydraul. Eng. 119, 1094-1117.

Gardner, J.V., Hughes Clarke, J.E., Mayer, L.A., 1999. Multibeam mapping of the Long Beach, California, continental shelf. Open-File Report, pp. 99-360.

Gee, M.J.R., Masson, D.G., Watts, A.B., Allen, P.A., 1999. The Saharan Debris Flow: An insight into the mechanics of 
long runout submarine debris flows. Sedimentology 46, 317355.

Grim, P.J., 1992. Dissemination of NOAA/NOS EEZ multibeam bathymetric data. In: Lockwood, M., McGregor, B.A. (Eds.), 1991 Exclusive Economic Zone Symposium, Working Together in the Pacific EEZ Proceedings. US Geological Survey Circular 1092, pp. 102-109.

Hopfinger, E.J., 1983. Snow avalanche motion and related phenomena. Annu. Rev. Fluid Mech. 15, 47-76.

Imran, J., Parker, G., 1998. A numerical model of channel inception on submarine fans. J. Geophys. Res. 103, 12191238.

Jopling, A.V., Richardson, E.V., 1966. Backset bedding developed in shooting flows in laboratory experiments. J. Sediment. Petrol. 36, 821-824.

Kneller, B., Buckee, C., 2000. The structure and fluid mechanics of turbidity currents: a review of some recent studies and their geological implications. Sedimentology 47 (Suppl. 1), 62-94.

Komar, P.D., 1971. Hydraulic jumps in turbidity currents. Geol. Soc. Am. Bull. 82, 1477-1488.

Komar, P.D., 1975. Supercritical flow in density currents: A discussion. J. Sediment. Petrol. 45, 747-749.

Le Pichon, X.L., Renard, V., 1982. Avalanching: A major process of erosion and transport in deep-sea canyons: evidence from submersible and multi-narrow beam surveys. In: Scrutton, R.S., Talwani, M. (Eds.), The Ocean Floor. Wiley, New York, pp. 113-128.

Liestøl, O., 1974. Avalanche plunge pool effect. Norsk Polarinst. Arb. 1972, 179-181.

Macías, J.L., Espindola, J.M., Bursik, M., Sheridan, M.F., 1998. Development of lithic-breccias in the 1982 pyroclastic flow deposits of El Chichon Volcano, Mexico. J. Volcanol. Geotherm. Res. 83, 173-196.

Major, J.J., 1997. Depositional processes in large-scale debris flow experiments. J. Geol. 105, 345-366.

Matthews, J.A., McCarroll, D., 1994. Snow-avalanche impact landforms in Breheimen, Southern Norway: Origin, age and palaeoclimatic implications. Arct. Alp. Res. 26, 103-115.

Middleton, G.V., 1993. Sediment deposition from turbidity currents. Annu. Rev. Earth Planet. Sci. 21, 89-114.

Mohrig, D., Whipple, K.X., Hondzo, M., Ellic, C., Parker, G., 1998. Hydroplaning of subaqueous debris flows. Geol. Soc. Am. Bull. 110, 387-394.

Mulder, T., Alexander, J., 2001. The physical character of subaqueous sedimentary density flows and their deposits. Sedimentology 48, 269-301.

Normark, W.R., Piper, D.J., 1991. Depositional consequences of turbidity currents reflection initiation processes and flow evolution. S.E.P.M. Spec. Publ. 46, pp. 207-230.

Piper, D.J.W., Shor, A.N., Hughes-Clarke, J.E., 1988. The 1929 Grand Banks earthquake, slump and turbidity current. Geol. Soc. Am. Spec. Paper 229, 77-92.

Poag, C.W., Mountain, G.S., 1987. Late Creataceous and Cenozoic evolution of the New Jersey continental slope and upper rise: an integration of borehole data with seismic reflection profiles. In: Poag, C.W., Watts, A.B. (Eds.), Init. Rep. DSDP 95, 673-724.

Pratson, L.F., Ryan, W.B.F., Mountain, G.S., Twitchell, D.C., 1994. Submarine canyon initiation by downslope eroding sediment flows: Evidence in late Cenozoic strata on the New Jersey continental slope. Geol. Soc. Am. Bull. 106, 395-412.

Pratson, L.F., Haxby, W.F., 1996. What is the slope of the US continental slope? Geology 24, 3-6.

Pratson, L., Imran, J., Parker, G., Syvitski, J.P.M., Hutton, E., 2001. Debris flows versus turbidity currents: a modelling comparison of their dynamics and deposits. In: Bouma, A., Stone, C.G. (Eds.), Fine Grained Turbidites. Assoc. Am. Pet. Geol. Mem. 72/S.E.P.M. Spec. Publ. no. 68.

Shor, A.N., Piper, D.J.W., Hughes-Clarke, J.E., Mayer, L.A., 1990. Giant flute-like scours and other erosional features formed by the 1929 Grand Banks turbidity current. Sedimentology 37, 631-645.

Smith, D.J., McCarthy, D.P., Luckman, B.H., 1994. Snowavalanche impact pools in the Canadian Rocky Mountains. Arct. Alp. Res. 26, 116-127.

Stow, D.A.V., Faugères, J.-C., Viana, A., Gonthier, E., 1998. Fossil contourites: A critical review. Sediment. Geol. 115, 3 31.

van Tassel, J., 1981. Silver abyssal plain carbonate turbidite: Flow characteristics. J. Geol. 89, 317-333.

Viana, A.R., Faugeres, J.-C., Stow, D.A.V., 1998. Bottom-current-controlled sand deposits - a review of modern shallow to deep-water environments. Sediment. Geol. 115, 53-80.

Weimer, P., Slatt, R.M., 1999. Turbidite systems, Part 1: Sequence and seismic stratigraphy. Leading Edge 18, 454-463.

Weirich, F., 1988. Field evidence for hydraulic jumps in subaqueous sediment flows. Nature 332, 626-629.

Weirich, F., 1989. The generation of turbidity currents by subaerial debris flows, California. Geol. Soc. Am. Bull. 101, 278-291.

Wilber, R.J., Milliman, J.D., Halley, R.B., 1990. Accumulation of bank-top sediment on the western slope of Great Bahama Bank: Rapid progradation of a carbonate megabank. Geology 18, 970-974. 